\title{
心臟ペースメーカ充電のための経皮的エネルギー伝送システム
}

\begin{tabular}{|c|c|c|}
\hline 正 員 & 西村 & 敏博 (大分大学) \\
\hline 正 員 & 江口 & 哲治 (大分工業高等学校) \\
\hline E 員 & 井上 & 猛（大分高等技術専門校） \\
\hline 員 & 斎藤 & 正男（東京電機大学） \\
\hline 非会备 & 前島 & 靖（田淵電機） \\
\hline$\Delta \Delta_{\theta}$ & 真山 & 文 (ユアサコーポレーション) \\
\hline 員 & 平地 & 克也(ユアサコーポレーション) \\
\hline
\end{tabular}

\section{A Transcutaneous Power Supply System for a Rechargeable Cardiac Pacemaker Battery}

Toshihiro Nishimura, Member (Oita University), Tetsuji Eguchi, Member (Oita Technical High School), Takeshi Inoue, Member (Institute of Oita High Technology), Masao Saito, Member (Tokyo Denki University), Yasushi Maejima, Non-member (Tabuchi Electric Co. Ltd.), Masafumi Majima, Non-member (YUASA Corporation), and Katsuya Hirachi, Member (YUASA Corporation)

Cardiac pacemaker has to be changed in three to five years for the battery life. A patients must be performed an operation whenever a patient is changed cardiac pacemaker. The method employing secondary rechargeable battery is researched to extend the battery life. The secondary rechargeable battery is transcutaneously charged from outside the body. This paper presents a transcutaneous energy transmission system for a rechargeable cardiac pacemaker battery. The transcutaneous energy transmission system is constructed with a high frequency resonant inverter, a transcutaneous transformer and a rectifier circuit. The secondary transformer is piled and the coupling coefficient and the conversion efficiency are measured with an experimental set up. The results show as follows. The best diameter of the primary center core is $15[\mathrm{~mm}]$. The best output voltage frequency is $10[\mathrm{kHz}]$.

キーワード：経皮的エネルギー伝送システム、高周波共振形インバータ、経皮トランス、ペースメーカ

\section{1. まえがき}

心臓ペースメーカ（以下ペースメーカと略す。）は不整脈 などの心臟に障害を持つ患者に用いられる治療機器である。 ペースメーカに内蔵される電池が消耗するために、ペースメ 一力は $3 \sim 5$ 年程度で交換する必要がある。心臟病、脳血管 障害の増加に伴いペースメーカを装着する患者は年々増え 続け、年閒約 2 万人の患者が外科手術を受けている(1)。患者 はペースメーカの交換の度に外科手術を受けね就ならず、患 者に多大な精神的な不快感を与える。

そこで、電池の長寿命化の有力な手段として、生体外から 非侵膻で皮膚を介して電力を伝送し繰り返し充電する二次 電池を用いる方法が検討されている(2) (5)。この方法では電 池の充電は皮膚を介して行わればならず、図 1 に示すような 経皮トランスを用いた経皮的エネルギー伝送システムが研 究されている。

数 $10[\mathrm{kHz}]$ の高周波インバータでトランスの一次コイルを
励磁し、ペースメーカの内部に収納された二次コイルに電力 を伝送する。ペースメーカの植え达み深さは最大 $10[\mathrm{~mm}]$ 程 度であり、トランスは $10[\mathrm{~mm}]$ の間隔を介して十分な電力を 伝送しなけ机ばならない。また、ペースメ一力は体内に埋め 込まれるものであるから、極力小型軽量にする必要があり、 ペースメーカの内部に収納される二次コイルは超小型軽量 としなければならない。



図 1 経皮的エネルギー伝送システム

Fig. 1. A transcutaneous energy transmission system. 
非侵䬶でエネルギー伝送を行う経皮的エネルギー伝送シ ステムは人工心臓の分野で多く研究されている(6) (10)。人工 心臓用の経皮的エネルギー伝送システムでは 20[W]程度の 電力を皮膚を挟み $70[\%]$ 以上の高い変換効率で伝送できる 例が報告されている(11)〜(14)。人工心臓の場合に比べてペース メ一カ用の経皮的エネルギー伝送システムでは、トランスの 体内側を超小型軽量に構成しなければならず、埋め込みの梁 さも大きい。そのため、トランスの結合率が低下し、二次側 に十分な磁束を伝えることが困難となる。また、ペースメー 力用では出力が $200[\mathrm{~mW}]$ 程度と小さいために電力変換効率 が低下し、トランスのエネルギー損失が大きい。そこで、本 研究では皮膚を介してペースメーカ駆動用の電池に電力を 伝送できる経皮的エネルギー伝送システムを検討した。

その結果、経皮トランスの形状の検討を行った結果、中足 の径が $15[\mathrm{~mm}]$ の時に変換效率が最大となり、ペースメーカ

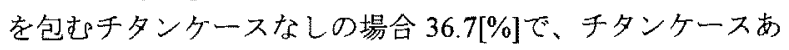
りの場合は 20.6[\%]であった。また、周波数の検討を行った 結果、チタンクースなしの場合で変換効率が最大となるのは $15[\mathrm{kHz}]$ の時で、その時の変換効率は 40.7[\%]であった。また、 チタンケースありの場合で変換効率が最大となるのは $10[\mathrm{kHz}]$ 時で、そのときの変換效率は 22.0[\%]であった。し たがって、チタンケースを用いる必要性から、10[kHz]が適 切であることがわかった。

\section{2. 経皮的エネルギー伝送システム}

$<2 \cdot 1>$ 経皮的エネルギ一伝送システムの構成 経皮 的エネルギー伝送システムを図1に示す。経皮的エネルギー 伀送システムは高周波共振形インバー夕、経皮トランス、整 流回路、および二次電池から構成される。経皮トランスの一 次側（体外）から高周波共振形インバータにより数 $10[\mathrm{kHz}]$ の高周波交流電圧を加光、皮虔を介して二次側（体内）に誘 導された起電力を整流してペースメーカに内蔵された二次 電池に充電する。

<2・2 > 経皮トランスの形状図 2 に経皮トランスの 構成を示す。経皮トランスは図 3 に示すように皮膚をはさん で一次側と二次側が対向して配置され、経皮的エネルギー伝 送実現させる。本研究では対向して配置される経皮トラン スの空隙距離をギャップと定義する。ペースメーカ用の経皮 的エネルギー伝送システムはトランスに $10[\mathrm{~mm}]$ 程度の大き なギャップを設けて動作させねばならない。大きなギャップ を設けるとトランスの結合率が低下し、電力の変換効率が悪 くなる。大きなギャップがある場合、トランスの結合率を増 加させるためにはトランスの直径を極力大きくしなければ ならない(2)。しかしトランスの二次側（体内側）は超小型軽 量にする必要がある。

そこで直径を大きくかつ体積を小とするため、図2(b)に 示すように非常に薄い形状のトランスを採用した。直径 $0.1[\mathrm{~mm}]$ の銅線䒚渦巻き状に 100 ターン巻き、二次側の経皮 トランスに鎖交した磁束が一次側に戻りやすくし、漏れ磁束 を低減させるために、螴面に厚さ $20[\mu \mathrm{m}]$ の円形アモルファ スシートを 2 枚張り付けている。一次側は図 2 (a)のような、
直径 36[mm]、厚さ $7[\mathrm{~mm}]$ のフェライトのポットコアを用い ている。中足の直径は $15[\mathrm{~mm}]$ とし、直径 $0.4[\mathrm{~mm}]$ の銅線を 120 ターン巻いている。

\section{3. 非侵警充電システムの損失解析}

<3・1 > 経皮トランスの等洒回路 図4 に経皮トラン スの一次側の等価回路を示す。 $\mathrm{R}_{\mathrm{in}}$ は電源の内部抵抗、 $\mathrm{I}_{\mathrm{in}(0)}$ は励磁電流、 $\mathrm{R}_{\mathrm{s1}}$ 'は一次側の巻線抵抗、 $\mathrm{k}$ は結合率、 $\mathrm{L}_{1}$ は卜 ランスの一次側のインダクタンス、 $\mathrm{L}_{\mathrm{L} 1}$ はトランスの一次側 の漏れインダクタンスである。また、R。は一次側および二 次側のコアの鉄損を表す等価抵抗である。

$$
\begin{aligned}
& \text { aa'からみたインピータンス } \dot{Z} \text { は } \\
& \qquad \dot{Z}=\frac{R_{0}{ }^{2} R_{s 1}{ }^{1}+\left(R_{s 1}{ }^{2}+\omega^{2} L_{1}{ }^{2}\right) R_{0}}{\left(R_{0}+R_{s 1}{ }^{1}\right)^{2}+\omega^{2} L_{1}{ }^{2}}+j \frac{R_{0}{ }^{2} \omega L_{1}}{\left(R_{0}+R_{s 1}{ }^{1}\right)^{2}+\omega^{2} L_{1}{ }^{2}} \\
& \ldots \ldots \ldots \ldots \ldots \ldots(1)
\end{aligned}
$$

よって回路のインピーダンスの抵抗分を $\mathrm{R}_{\mathrm{s} 1}$ とすると、

$$
R_{s 1}=\frac{R_{0}{ }^{2} R_{s 1}{ }^{\prime}+\left(R_{s 1}{ }^{\prime 2}+\omega^{2} L_{1}{ }^{2}\right) R_{0}}{\left(R_{0}+R_{s 1}{ }^{\prime}\right)^{2}+\omega^{2} L_{1}{ }^{2}} .
$$

となる。（2）式より鉄損を表す等洒抵抗 $\mathrm{R}_{0}$ を求めると、

$$
R_{0}=\frac{-\beta+\sqrt{\beta^{2}-4 \alpha \gamma}}{2 \alpha}
$$

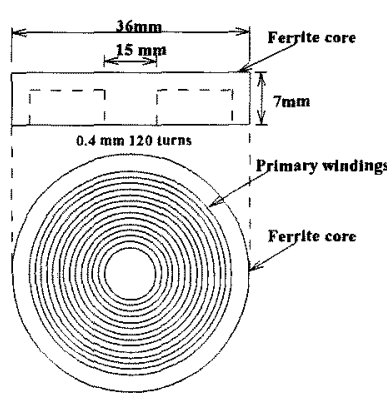

(a)一次側

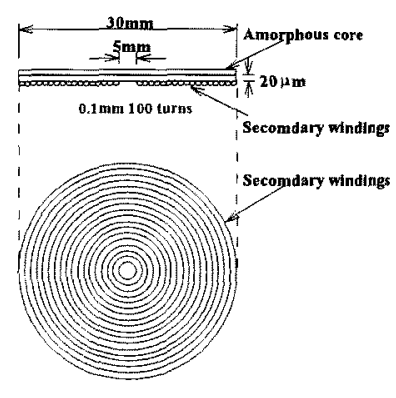

(b) 二次側
図 2 経皮トランスの構成

Fig.2. A constitution of a transcutaneous transformer.

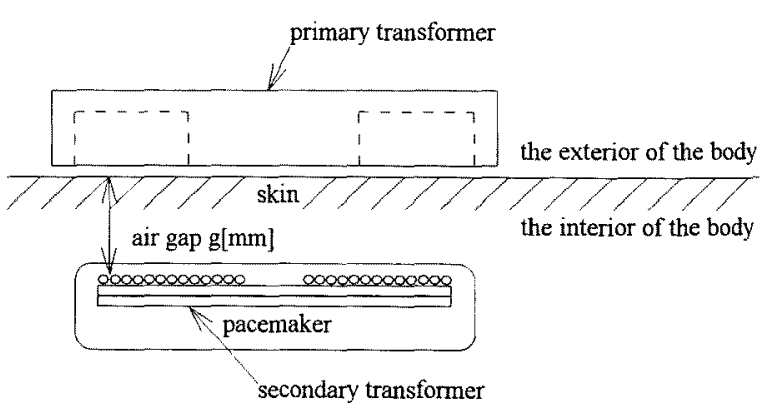

図 3 経皮トランスの配㯰

Fig. 3. A configuration of a transcutaneous transformer. 


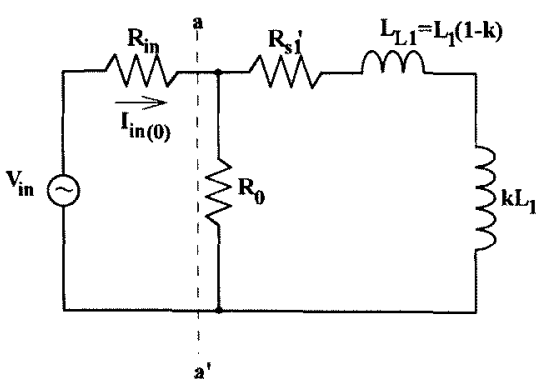

図 4 経皮トランスの一次側の等価回路

Fig.4. An equivalent circuit of primary transcutaneous transformer.

表 1 損失のシミュレーションに用いたパラメータの值

Table 1 . The value of the parameters using the simulation of the power loss.

\begin{tabular}{ccccccc}
\hline$g[\mathrm{~mm}]$ & $L_{l}[\mu \mathrm{H}]$ & $L_{2}[\mu \mathrm{H}]$ & $k$ & $R_{s !}[\Omega]$ & $R_{s \prime}[\Omega]$ & $R_{0}[\Omega]$ \\
\hline 8.0 & 490.3 & 1206.0 & 0.31 & 1.71 & 0.83 & 4310 \\
\hline 9.6 & 483.0 & 1173.0 & 0.24 & 1.70 & 0.83 & 4230 \\
\hline 11.2 & 476.7 & 1157.0 & 0.19 & 1.69 & 0.83 & 4168 \\
\hline
\end{tabular}

ただし、

$$
\begin{aligned}
& \alpha=R_{s 1}-R_{s 1}{ }^{\prime} \\
& \beta=2 R_{s 1} R_{s 1}{ }^{1}-R_{s 1}{ }^{2}-\omega^{2} L_{1}{ }^{2} \\
& \gamma=R_{s 1} \omega^{2} L_{1}{ }^{2}
\end{aligned}
$$

となる。

$<3 \cdot 2>$ 損失の検討 $\mathrm{R}_{s 1} 、 \mathrm{R}_{\mathrm{s1}}$ 、、 $\mathrm{L}_{1} 、$ 测定可能なの で、これらの値を測定し、（3）式より $\mathrm{R}_{0}$ を算出した。実 際に一次側の交流電圧 $V_{\text {in }}$ の振幅を 10[V]とし、100[ $\Omega$ ]の負 荷抵抗を二次側に接続した回路を図 5 に示す。k、L および $\mathrm{R}_{82}$ 'は測定可能なので、PSpice を用いて一次銅損 $\mathrm{W}_{1}$ '、鉄損 $\mathrm{W}_{\mathrm{I}}$ 、二次銅損 $\mathrm{W}_{2}{ }^{\prime}$ をギャップを変えてシミュレーションし た。PSpiceを用いて解析するにあたり、まず、電源は正弦波 電源で置き換え、トランスのモデル(15) は一次側および二次 側のインダクタンスと結合係数を使用した。ギャップg が 8.0、9.6、11.2[mm]の場合のパラメー夕の值を表 1 に示す。

PSpice で $\mathrm{R}_{\mathrm{s} 1}$ 、、 $\mathrm{R}_{0} 、 \mathrm{R}_{\mathrm{s2}}$ 'に流れる電流波形をトランジェント 解析で計算し、これらの実効值をPSpice のRMS 関数 ${ }^{(16)}$ 用いて求め、これらの抵抗值と電流の二乗の積から損失を求 めた。その結果を図6に示す。

一次銅損 $\mathrm{W}_{1}$ 、鉄損 $\mathrm{W}_{1}$ 、二次銅損 $\mathrm{W}_{2}{ }^{\prime}$ のシミュレーショ ン結果および実験結果はよく一致している。この結果から、 鉄損および一次銅損の占める割合が多いことが分かる。また ギャップが大きくなるにしたがい結合率が低下するので電 力の伝送効率が悪くなり、二次銅損は低下することが分かる。

\section{4. 磁束密度分布のシミュレーション}

経皮トランスの一次側のフェライトコアの適切な形状を 検討するために、積分方程式法による磁束密度分布のシミュ レーションを行った。一次側のフェライトコアと二次側のア モルファスシートコアは中心軸に対して回転対称である

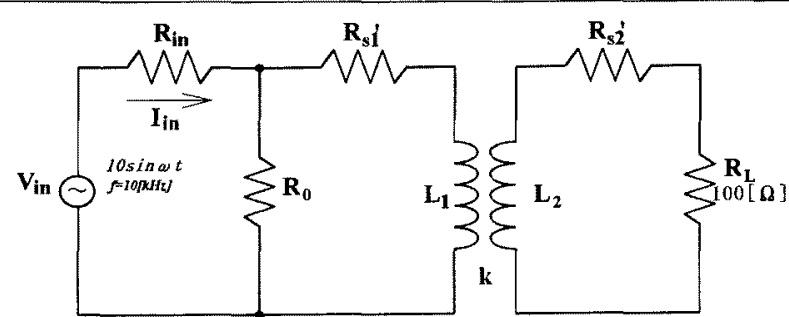

図 5 PSpiceを用いたシミュレーションのための回路 Fig.5. An equivalent circuit for simulation using a PSpice circuit simulator.

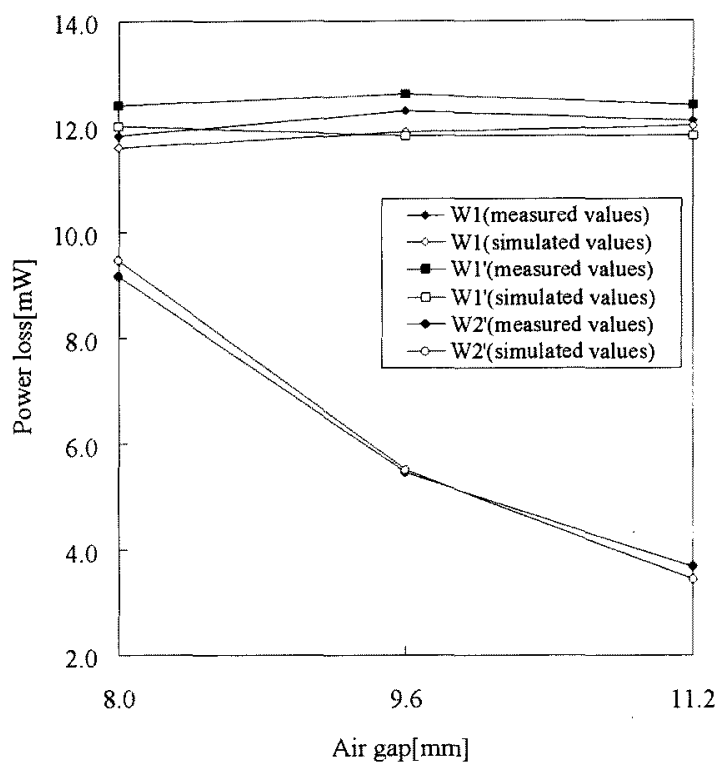

図 6 銅損および鉄損のシミュレーション結果

Fig.6. The simulation results of copper loss and iron loss

ので、中心軸を通る断面の右半分または左半分の形状を与え るだけで空間の磁束密度分布を計算することができる。

そこで、フェライトコアの断面の右半分を 12 個の要素、 アモルファスシートコアの断面の右半分を 30 個の要素にそ れぞれ分割する。また、空間の部分は細かな要素に分割する。 フェライトコアの断面の右半分 12 個の要素でコの字形に囲 まれた部分に一様に流れる直流電流を70[AT]にして磁束密 度分布のシミュレーションを行った。

図 7 にコライトコアの中足の直径を変えた場合の磁束 密度分布の変化を示す。各要素に記されている知印は要素の 中心部分の磁束の方向と磁束密度の大きさを示している。図 示されている等高線は等磁束密度線であり、最も外側の磁束 密度が最小值で、磁束密度の值は中心に行くほど大きくなる。 等高線は図中に記述されている最大磁束密度 $\mathrm{B}_{\max }$ の 1/21の 間隔で大きくなるように、要素を切った空閒中における $\mathrm{B}_{\max }$ の $1 / 21$ の閒隔で 20 本引いている。

図 7 (a)にフェライトコアの中足の直径が $3[\mathrm{~mm}]$ の時の磁 束分布密度を示す。中足近傍の磁束密度は高いが、フェライ 


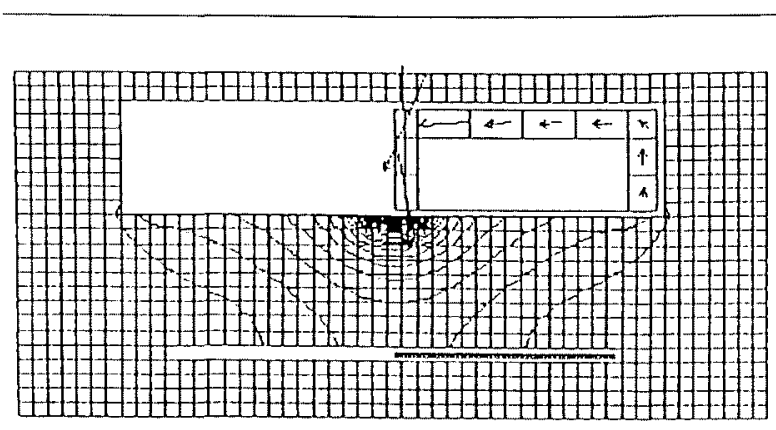

$B_{\max }=256$ [gauss]

(a) 中足の直径 $3[\mathrm{~mm}]$ の場合



$\mathrm{B}_{\max }=160$ [gauss]

(b) 中足の真径 $15[\mathrm{~mm}]$ の場合

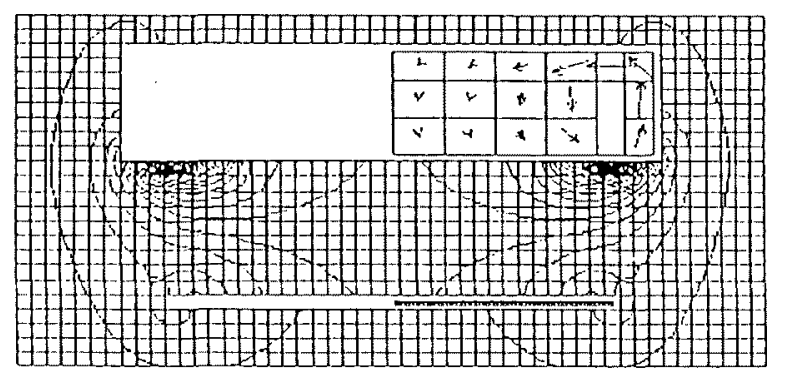

$$
B_{\max }=247 \text { [gauss] }
$$

(c) 中足の直径 $28[\mathrm{~mm}]$ の場合

図 7 磁束密度分布のシミュレーション

Fig.7. Simulation results of the magnetic flux density distribution.

トコアから離れるにしたがって磁束密度は急激に減少し、二 次側のコアにはごく弱い磁束しか鎖交してないことがわか る。これは、中足の直径が小さいために、一次側コアの中足 とトランスの二次側の中心の間における空間部分の磁路の 断面積が小さく、一次側と二次側のコアの間の空間部分の磁 気抵抗が極めて大きくなり、大きな磁束を発生できなかった ためと考えられる。

図 7 (c)にフェライトコアの中足の直径が $28[\mathrm{~mm}]$ の時の磁 束分布密度を示す。中足と外足の間隔吕狭いため、中足の外 周部から外足にかけて磁束が集中し、二次側のコアにはあま り磁束が鎖交していないことがわかる。

図 7 (b)フェライトコアの中足の直径が $15[\mathrm{~mm}]$ の時の磁束 分布密度を示す。等高線が比較的遠くまで広がっており、二 次側のコアにも磁束が鎖交していることがわかる。



図 8 実験装置

Fig.8. Experimental setup.

\section{5. 実 験}

<5・1>実倹方法 ペースメーカおよび経皮トランス を体内に植え込む場合、ケースに入れて植え込む必要がある。 本研究では腐食しにくいチタンを用いケースとして使用し た。図 8にその実験装置を示す。チタンに磁束が鎖交すると、 チタン表面に渦電流が流れるので、エネルギー損失が発生す る。これをチタン損と呼ぶことにする。

実験ではチタンがある場合とない場合に分けて測定を行

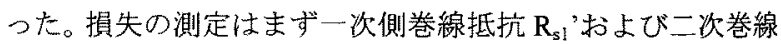
抵抗 $\mathrm{R}_{\mathrm{s} 2}$ 'を測定する。次に、一次側および二次側のコアのあ る状態で一次側の抵抗 $\mathrm{R}_{\mathrm{s} 1}$ を測定する。さらに、チタンを入 れた状態で一次側の抵抗の増加分 $\mathrm{R}_{\mathrm{Ti}}$ を測定する。一次銅損 $\mathrm{W}_{1}$ 、二次銅損 $\mathrm{W}_{2}$ 、鉄損 $\mathrm{W}_{1}$ 、およびチタン損 $\mathrm{W}_{\mathrm{Ti}}$ は次式で 袁される。

$$
\begin{aligned}
& W_{1}^{\prime}=I_{1}^{2} \times R_{s 1}{ }^{\prime} \\
& W_{2}{ }^{\prime}=I_{2}{ }^{2} \times R_{s 2}{ }^{\prime} \\
& W_{1}=I_{1}{ }^{2} \times\left(R_{s 1}-R_{s 1}{ }^{\prime}\right) \\
& W_{T i}=I_{1}{ }^{2} \times R_{T i} \ldots \ldots \ldots
\end{aligned}
$$

このようにして負荷をか外、各損失の測定を行った。

\section{$<5 \cdot 2>$ 一次側のコアの中足の直径を变えた場合の実}

験結果図9に一次側の経皮トランスのコアの中足の径 を変えた場合の実験結果を示す。巻数は一次巻線がコアに可 能な限り多く巻き、出力が $170[\mathrm{~mW}]$ 一定となるように測定 した。また、周波数は $10[\mathrm{kHz}]$ 、ギャップは $10[\mathrm{~mm}]$ に固定し た。図 9 (a)、9(b)、9(c)、および図 9 (d)はそれぞれ経皮卜 ランスの一次入力電流、銅損、鉄損、および変換効率を示し ている。 


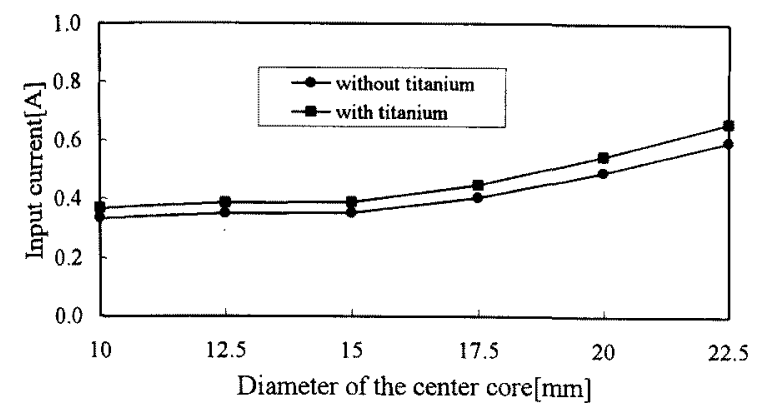

(a) Input current

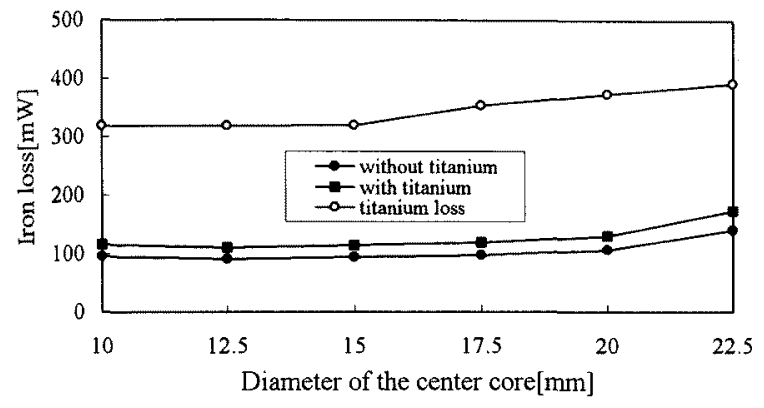

(c) Iron loss

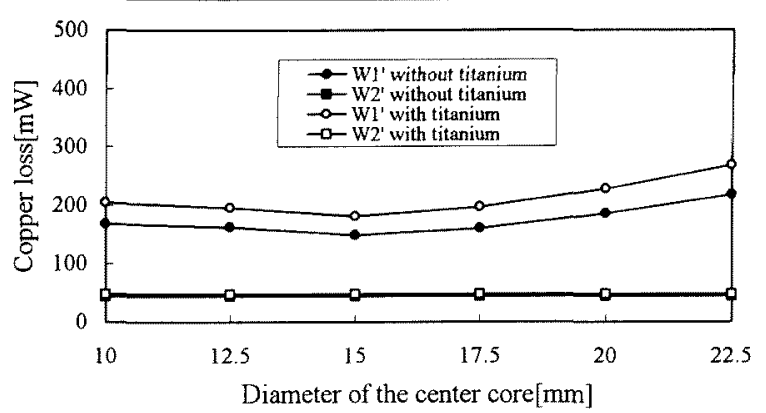

(b) Copper loss

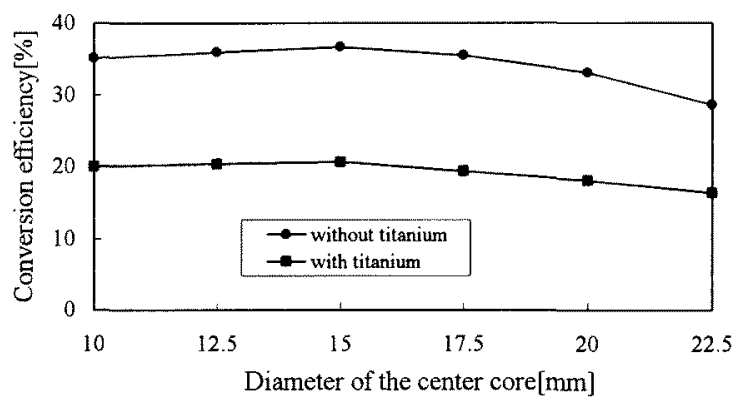

(d) Conversion efficiency

図 9 一次側の経皮トランスのコアの中足の径を変えた場合の実験結果

Fig.9. Experimental results when the diameter of the center core is changed.

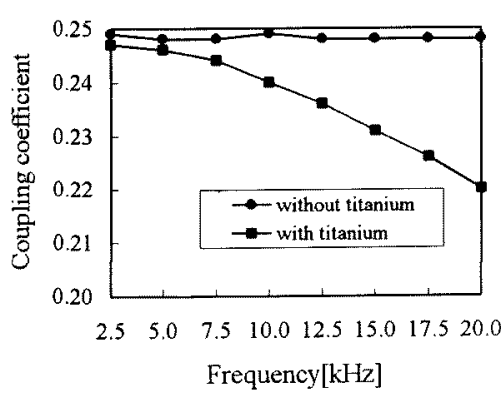

(a) Coupling coefficient

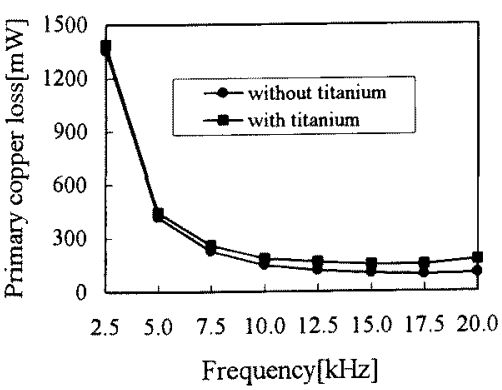

(d) Primary copper loss

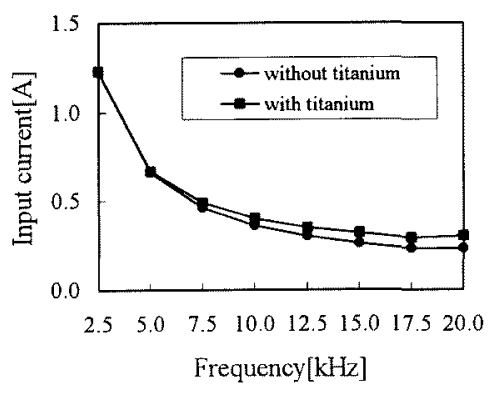

(b) Input current

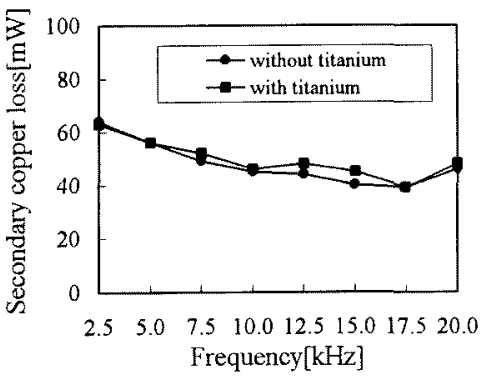

(e) Secondary copper loss

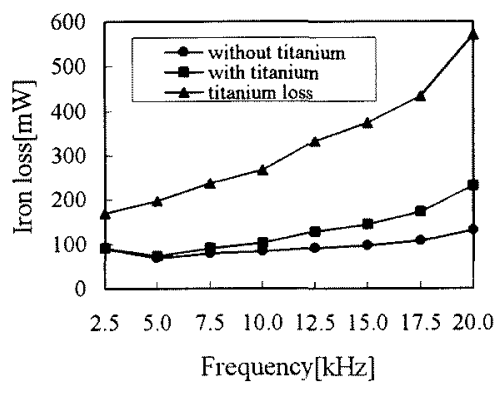

(c) Iron loss

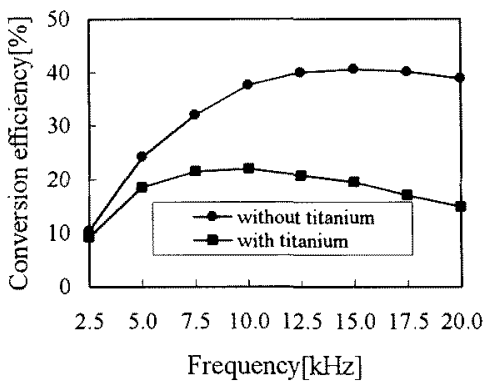

(f) Conversion efficiency

図 10 周波数変えた場合の実験結果

Fig.10. Experimental results when frequency is changed. 
図9(a)に执いて、一次入力電流はチタンケースに発生する 渦電流により増大寸ることがわかる。チタン損は鉄損より多 いことが図 9 (c)からわかる。図 9 (b)からチタンがない場合は 銅損はほぼ一定であるのに対し、チタンがある場合は中足の 径 $15[\mathrm{~mm}]$ を境に增加する。15[mm]より小さい領域では、一 次入力電流はほぼ一定であるが、巻き数が多いため銅損は増 加する。15[mm]より大きい頜域で銅損が增加しているのは一 次入力電流が大きくなるためである。鉄損およびチタン損は 中足の径 $15[\mathrm{~mm}]$ までは変化しないが、15[mm]を超えると一 次入力電流増加に上り二次側に鎖交しない漏れ磁束が鉄心 およびチタンと鎖交するので渦電流損が増加し鉄損および チタン損が増加する。

したがって、銅損、鉄損、チタン損を合わせた損失は $15[\mathrm{~mm}]$ が最小となり、図 $9(\mathrm{~d})$ から、中足の径が $15[\mathrm{~mm}]$ の時に変換 効率が最大となることがわかる。そのときの変換効率は千夕 ンケースなしの場合 36.7[\%]で、チタンケースありの場合は 20.6[\%]まで低下することがわかる。したがって、図7 の磁束 密度分布のシミュレーションの結果を考慮すると、外径が $36[\mathrm{~mm}]$ の場合、中足の直径は $15[\mathrm{~mm}]$ 、すなわち外径と内径 の比で 12:5が適切であることがわかる。

$<5 \cdot 2>$ 周波数を变えた場合の実絤結果図 10 に周 波数を変えた場合の実験結果を示す。図 $10(\mathrm{a}) 、 10(\mathrm{~b}) 、 1$

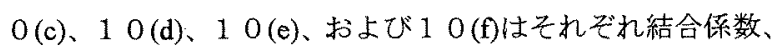
一次入力電流、鉄損、一次銅損、二次銅損、変換效率学示し ている。中足の直径は $15[\mathrm{~mm}] 、 キ ゙ ャ ッ フ ゚ は 10[\mathrm{~mm}] に$ 固定し、 出力は $170[\mathrm{~mW}]$ 一定となるように測定した。

図 10 (a)から、周波数が高くなると、チタンケースがある 場合、チタン損が発生するために結合係数が低下することが わかる。図 10 (b)から、チタンケースが女る場合、チタン損 の分だけ損失が増えるので、一次入力電流は大きくなること がわかる。

次に鉄損について検吋する。ヒステリシス損 $\mathrm{W}_{\mathrm{h}}$ および渦 電流損 $\mathrm{W}_{\mathrm{e}}$ は周波数 $\mathrm{f}$ および最大磁柬密度 $\mathrm{B}_{\mathrm{m}}$ が変化する場合、 次式 (17) で表される。

$$
\begin{aligned}
& W_{h} \propto f B_{m}^{1.6} \\
& W_{e} \propto f^{2} B_{m}{ }^{2} .
\end{aligned}
$$

したがって、これらの和である鉄損 $\mathrm{W}_{\mathrm{i}}$ は次式のように表さ れると一般的に解釈しても差し支えないと考えられる。

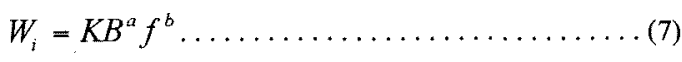

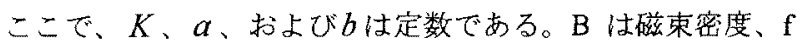
は周波数である。図 10 (c)から、周波数が低い場合、一次入 力電流は大きくなり磁束密度が大きくなるが、周波数が低い ので鉄損は小さいことがわかる。周波数が高くなると、リア クタンスが大きくなるために一次入力電流は減少するが、周 波数が高いので鉄損が大きくなることがわかる。チタン損も 鉄損同様に周波数が高くなると大きくなることがわかる。千 タン損は鉄損の 2 倍程度出ていることがわかる。

図 10 (d)および 10 (e)において、周波数が高い場合、リア クタンスが大きくなるので入力電流が減少し銅損が低減さ れることがわかる。周波数が $2.5[\mathrm{kHz}]$ の場合の入力電流は千 タンのない場合で 1.22[A]、チタンのある場合で 1.23[A]であ
るのに対し、周波数が $10[\mathrm{kHz}]$ 場合、チタンのない場合で 0.36[A]、チタンのある場合で 0.40[A]となり、リアクタンス が大きくなるので入力電流は減少する。銅損は周波数が $2.5[\mathrm{kHz}]$ でチタンのない場合 $1355[\mathrm{~mW}]$ 、チタンのある場合 $1386[\mathrm{~mW}$ 、周波数が 10[kHz]でチタンのない場合 $147[\mathrm{~mW}$ 、 チタンのある場合 $182[\mathrm{~mW}]$ となり、周波数が高い場合では入 力電流が減少するため銅損が低減する。特に、一次銅損の低 減の著しい原因は、二次出力電流に対して一次入力電流が大 きいためである。

図10(f)より、チタンのない場合で変換効率が最大となる のは周波数が $15[\mathrm{kHz}]$ の時で、その時の変換効率は $40.7[\%]$ である。また、チタンのある場合で変換効率が最大となるの は周波数が $10[\mathrm{kHz}]$ の時で、そのときの変換効率は 22.0[\%] である。したがって、チタンケースを用いる必要性から、周 波数は10[kHz]が適切であることがわかる。

\section{6.むすび}

本研究では生体外から非侵襲で充電可能な経皮的エネル ギ一伝送システムを検討した。経皮トランスの等価回路を解 析し、損失の分析を行った。また、磁束密度分布のシミュレ ーションを行い、一次側のコアの形状の検討を行った。さら に、実験で経皮的エネルギー伝送システムの特性を測定した。 その結果を以下に示す。

(1)一次側の経皮トランスの外径が $36[\mathrm{~mm}]$ の場合、一次側の コアの中足の直径が $15[\mathrm{~mm}]$ の時に変換効率が最大となる。 また、磁束密度分布シミュレーションの結果からも、中足 の直径は $15[\mathrm{~mm}]$ 、すなわち外径と内径の比で $12: 5$ が適切 である。

(2)変換効率が最大となる周波数は $10[\mathrm{kHz}]$ である。

これらの結果を踏まえて、今後は経皮トランスの二次側の 改良を换討し、温度上昇を踏まえながら、さらなる損失の低 減を行っていきたい。本研究の一部は、平成 $6 、 7$ 年度文部 省科学研究費一般研究 (C) 研究課題番号:0680503 7 の援助によった。感謝します。

(平成 8 年 9 月 19 日受付、平成 9 年 4 月 24 日再受付)

\section{文献}

(1)青木和一：「頼りになります心臓ペースメーカ」，新電気， 23〜29, オーム社 (Jan.1994)

(2)平地克也・真嶋政文 - 桑名宏二 ・前島靖 - 西村敏博：「心 臓ペースメーカー用経皮的充電システムのシミュレーシ ヨンによる検討」，電気学会研究会資料 SPC-94-15, 1 6 (平 6-1)

(3)西村敏博 - 江口哲治 - 中阔睦雄 - 真嶋政文・前島靖・平地 克也・斎藤正男：「心藏ペースメーカー電源充電のための 経皮的 Transformer $の$ 形状の検討了，電気学会研究会資料 MBE-94-12，29 38 (平 6-12)

(4)T.Nishimura, T.Eguchi, K.Hirachi, Y.Maejima, K.Kuwana, 
M.Saito:"A Large Air Gap Flat Transformer for A Transcutaneous Energy Transmission System", IEEE PESC'94 RECORD Volume2, 1323 1329, 1994.

(5)T.Nishimura, T.Eguchi, T.Inoue, M.Nakaoka, K.Hirachi, M.Maejima, K.Kuwana, Y.Maejima, K.Saito, and M.Saito:"A Transcutaneous Energy Transformer for A Non Invansive Rechargeable Cardiac Pacemaker Battery", PROCEEDINGS ICPE'95 (INTERNATIONAL CONFERENCE ON POWER ELECTRONICS), 337-342, 1995.

(6)松木英敏・椎木元晴 - 山本孝幸・村上孝一：「電磁形人工 心臓駆動用経皮的薄形変圧器の特性」, 電学論 $\mathrm{A}, 111$, 807 810（平 3-9）

(7)Nishimura T, Saito M \& Lorenz L:"An energy conversion system for an implantable artificial heart", 3. European Conf. on Power Electronics \& Applications, pp.755-760, Vol.2, October 1989.

(8)松木英敏 - 椎木元晴 · 渡辺忠昭 - 村上孝一 ·撫原浩嗣 - 山 本孝幸：「アモルファス磁性線を用いた人工心臟用経皮的 薄型変圧器の特性評価」, 日本応用磁気学会誌, 14, 493-496 (1990)

(9)Y.Mitamura, E.Okamoto, A.Hirano, and T.Mikami "Development of an Implantable Motor-Driven Assist Pump System", IEEE Trans. Biomedical Engineering, ppl46-156, Vol 37, February 1990.

(10)越地耕二・三田村好矩：「V . 経皮的エネルギー伝送と 光テレメトリ」, 電学論 D, 115, 194 195, (平 7-3)

(11)三田村好矩 - 岡本英治 :「生体内埋込機器の電源仕様」, 電気学会研究会資料 MBE-94-8， 1 6 (平 6-12)

(12)平野 篤 -三田村好矩・岡本英治・三上智久：「経皮工 ネルギー伝送装置の開発」，電気学会研究会資料 MBE$86-24 ， 17 \sim 24$ (昭 62)

(13)椎木元晴・松木英敏・山本孝幸・村上孝一：「人工心臓 用非接触電力伝送コイルの伝送効率に関する検討」，電気 学会研究会資料 MAG-91-199，1-7 (平 3-9)

(14)鈴木篤史・松木英敏・仁田新一・橋本弘之：「振動ポン プ型人工心臓用非接触電磁駆動システムの構成に関する 基礎的検討」，電気学会研究会資料 MBE-94-15，51-60 (平 6-12)

(15)岡村妯夫：「パソコン用電子回路シミュレータ PSpice(C Q版)」, C Q 出版社, P.42, 平 4-1)

(16)岡村廸夫：「パソコン用電子回路シミュレータ PSpice(C Q版)」, C Q出版社, P.79, 平 4-1)

(17)桜井良文：「現代磁気工学」, p.32, 才一ム社（昭 61）



(正員) 1950年4月9日生。1978年大分大学 工学部電気工学科卒業。同年大分大学工学部 電気電子工学科に勤務、現在に至る。工学博 土 (東京大学)。半導体電力変換工学、医用 生体工学、超音波音響工学、画像工学、完全 埋込型人工心臓システム、心臓ペースメーカ、 人工臓器のエネルギー転送システムなどの
研究教育に従事。電子情報通信学会、日本ME学会、日本超 音波医学会、LST学会、IEEE正員。IEEE PESC'96および PESC'97 Program Committee Member。

江口 哲治 （正員）1967年2月20日生。1991年3月大分 大学大学院工学研究科電気工学専攻修士課 程修了。同年4月より大分県立大分工業高 等学校電気科勤務。医用生体工学、パワー エレクトロニクス、心臓ペースメーカのため の経皮的エネルギー伝送に関する研究に従 事。IEEE正員。

井上猛 (正員) 1962年1月4日生。1986年3月大分

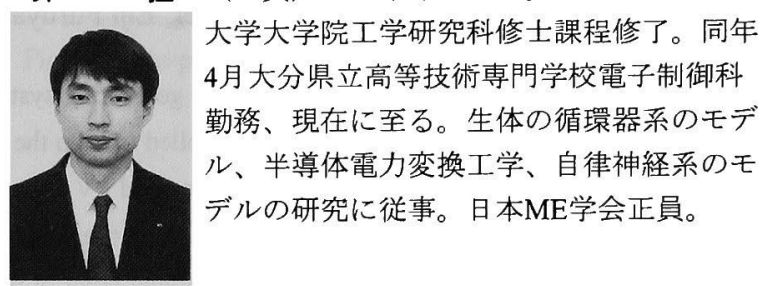

斎藤 正男 （正員）1956年東京大学工学部卒業。1962

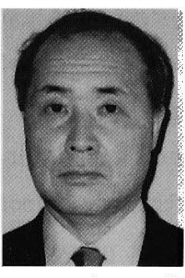
年同大学大学院博士課程修了。同大学工学 部講師、助教授を経て、1974年同医学部教 授。同大学退官後、東京電機大学教授。工 学博士。回路システム理論、医用生体工学 の研究教育に従事。日本ME学会会長、日 本ハイパーサーミア学会副会長、LST学会会 長、国際ME学会会長、日本学術会議医用生体工学研連委員 長を歴任。電子情報通信学会稲田賞、論文賞、日本ME学会 論文賞受賞。国際ME学会名誉会員。IEEE Fellow。

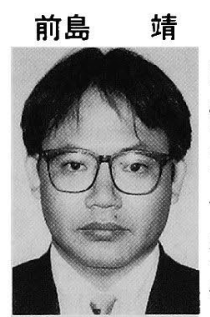

(非会員) 1962年7月15日生。1986年3月関 西大学工学部電気工学科卒業。同年4月田淵 電機株式会社入社、現在に至る。スイッチ ング電源、パワーデバイス、心臓ペースメ 一カのエネルギー転送システムに関する研 究開発に従事。電子情報通信学会、日本ME 学会正員。

\section{真嶋 政文 （非会員）写真および略歴省略。}

平地 克也 (正員) 1954年5月22日生。1979年3月京都


大学工学部電気工学科卒業。1979年4月株式 会社ユアサ・コーポレーション入社、現在 に至る。スイッチング電源、無停電電源装 置などの研究開発に従事。現在パワーエレ クトロニクス電源事業部開発部に所属。電 気学会正員、パワーエレクトロニクス研究会 会員。 